\title{
Vascular Markers among Young Women with CVD Risk Factors
}

(Penanda Vaskular dalam Kalangan Wanita Muda dengan Faktor Risiko CVD)

\author{
AMILIA AMINUdDIN*, AZIZAh UguSMAn, NORIZAM SALAMT \& MUSILAWATI MUHAJIR
}

\begin{abstract}
Data pertaining to carotid intima-media thickness (CIMT), carotid-femoral pulse wave velocity (PWVcf), augmentation index (AI), and C-reactive protein (CRP) are less studied among young Asian women. The objectives of this study were to determine the associations between these vascular markers with other cardiovascular (CVD) risk factors and future CVD risks; and secondly, to determine the associations between the markers themselves among young women. One hundred and forty-eight young women who were healthy, or having any CVD risk factor, were recruited. They were divided into a healthy group $(H G, n=71)$ and a risk group $(R G, n=77)$. The parameters measured included body anthropometry, blood pressure (BP), CIMT, PWVCf, AI, CRP, blood sugar, and lipid profiles. The future CVD risk was expressed in short and long term Framingham Risk Scores (FRS). The data was analysed via SPSS and p-value $<0.05$ was accepted as significant. The $R G$ had significantly higher PWVcf, AI, and hs-CRP when compared to HG. All of the markers were associated with CVD risk factors and the long-term FRS. The independent variable for CIMT was age $\left(R^{2}=0.11\right)$, while PWVcf was determined by diastolic BP and age $\left(R^{2}=0.29\right)$. AI was independently determined by age, heart rate, and LDL $\left(R^{2}=0.28\right)$, while for $C R P$, it was weight and HDL $\left(R^{2}=0.30\right)$. In conclusion, among the young women with CVD risk factor, CIMT, PWVcf, AI, and hs-CRP can be used to assess their risk of future CVD. No associations were observed between the markers themselves, which suggests that every marker reflects a different entity. They should be measured independently for a complete vascular assessment.
\end{abstract}

Keywords: Carotid artery; vascular stiffness; young adults

\section{ABSTRAK}

Maklumat berkaitan ketebalan intima media arteri karotid (CIMT), halaju gelombang nadi arteri karotid femor (PWVcf), indeks augmentasi (AI) dan protein C-Reaktif (CRP) kurang dikaji dalam kalangan belia wanita Asia. Objektif kajian ini adalah menentukan hubungan antara penanda saluran darah tersebut dengan faktor-faktor risiko CVD yang lain serta risiko CVD pada masa depan, dan kedua adalah untuk menentukan hubungan penanda saluran darah tersebut sesama sendiri dalam kalangan wanita muda. Seramai seratus empat puluh lapan wanita muda yang sihat atau mempunyai faktor risiko CVD direkrut. Mereka dibahagikan kepada kumpulan sihat (HG, $n=71)$ dan kumpulan berisiko $(R G, n=77)$. Parameter yang diukur meliputi antropometri badan, tekanan darah (BP), CIMT, PWVcf, AI, CRP, glukosa darah dan profil lipid. Risiko CVD pada masa depan dibentangkan dalam bentuk Skor Risiko Framingham (FRS) jangka masa panjang dan pendek. Data dianalisis menggunakan SPSS dan nilai $p<0.05$ diterima sebagai signifikan. Kumpulan RG mempunyai PWVcf, AI dan Hs-CRP yang lebih ting gi apabila dibandingkan dengan HG. Kesemua penanda saluran darah ini mempunyai hubungan dengan faktor risiko CVD dan FRS jangka masa panjang. Variabel tidak bersandar bagi CIMT adalah umur $\left(R^{2}=0.11\right)$ sementara PWVcf ditentukan oleh BP diastolik dan umur $\left(R^{2}=0.29\right)$. AI ditentukan secara bebas oleh umur, kadar nadi dan LDL $\left(R^{2}=0.30\right)$ manakala CRP pula ialah berat dan $H D L\left(R^{2}=0.30\right)$. Tiada hubungan yang dicerap dalam kalangan penanda saluran darah tersebut. Kesimpulannya, dalam kalangan wanita muda dengan faktor risiko CVD, CIMT, PWVcf, AI dan hs-CRP boleh digunakan untuk menilai risiko CVD pada masa depan. Tiada hubungan didapati dalam kalangan penanda tersebut dan dicadangkan bahawa setiap penanda saluran darah menunjukkan entiti yang berbeza dan masing-masing perlu diukur bagi penilaian menyeluruh salur darah.

Kata kunci: Arteri karotid; kekakuan vaskular; wanita muda

\section{INTRODUCTION}

Cardiovascular disease (CVD) occurs 7 to 10 years later in women when compared to men (Maas \& Appleman 2010). The risk of premature coronary artery disease (CAD) is also higher in men (Shah et al. 2015). This is believed to be due to the presence of oestrogen in women during the reproductive age that reduces the chance of having
CVD (Faustino et al. 2010). Nevertheless, the assessment of a CVD risk and the screening of CVD risk factor among women, especially at the reproductive age, should not be ignored, since women with CVD risk factor may develop CVD at a younger age. Women with a history of gestational diabetes and preeclampsia during pregnancy, or polycystic ovarian syndrome complicated with other 
CVD risk factors, such as obesity and dyslipidemia, are at risk of developing CVD (Robert et al. 2010). In addition, the CVD risk is increased after menopause, following the reduction in oestrogen level. It was observed that the mortality rate among women after myocardial infarction (MI) and stroke were $32 \%$ and $8 \%$ higher than men were, respectively. For women with a CVD risk factor, such as smoking and diabetes mellitus, the prognosis is worse when compared to men (Maas \& Applemen 2010). Other risk factors for CVD, in general, are a family history of premature coronary artery disease and an increased body mass index (BMI).

The rate of progression of atherosclerosis is different between individuals. Several risk models have been developed based on conventional risk factors, in order to estimate a future cardiovascular event. However, these risk equations have several limitations. They may not be accurate for women and Asian subjects, do not include a duration of risk exposure, and they do not provide a lifetime risk estimate (Papageorgiou et al. 2017). The models also tend to underestimate or overestimate an individual risk (Papageorgiou et al. 2017). Thus, several other markers of CVD have been established, such as $\mathrm{C}$ reactive protein (CRP), carotid artery intima-media thickness (CIMT), carotid-femoral pulse wave velocity (PWVcf), and augmentation index (AI) (Comsa et al. 2018; Greenland et al. 2010). These markers are used to estimate the degree of subclinical vascular damage among the subjects and help in the management of a CVD risk factor, especially for those with a low and intermediate risk (Goff et al. 2014). For example, those subjects with a family history of a premature CAD and a high level of subclinical vascular damage may be directed for early treatment, such as statin (Mulders et al. 2012). Subclinical vascular damage can also be an assessment tool, in order to determine the effects of any supplement (Talari et al. 2018).

CRP is a marker of inflammation that is involved in the pathogenesis of atherosclerosis, such as endothelial dysfunction, immune cell activation, and inflammatory response (Griselli et al. 1999). CRP has been associated with an increased risk of CVD mortality among healthy women (Ridker et al. 2002) and CRP was a stronger predictor of cardiovascular $(\mathrm{CV})$ events when compared to low density lipoprotein (LDL) cholesterol (Ridker et al. 2002). High sensitivity C-reactive protein (hs-CRP) has been used in calculations for a 10-year CVD risk among women (Reynolds Risk Score) (Ridker et al. 2007). In Malaysia, an increased CRP among patients with ischemic stroke has been associated with a poorer functional outcome (Hamidon et al. 2004). CIMT is measured via ultrasound and it may detect early stages of atherosclerotic disease (Touboul et al. 2012). The method is non-invasive and is reproducible in identifying a CVD risk (Stein et al. 2008). CIMT has been associated with risk of CVD, such as myocardial infarction, stroke, and coronary heart disease (CHD) related mortality (Chambless et al. 2000, 1997). The ability of CIMT to predict future CVD events is independent of CVD conventional risk factors (Stein et al. 2008). Imaging of atherosclerosis by the CIMT technique is able to detect the disease, which may be used for the reclassification of those individuals who are at low and intermediate risk. This may also help to strategise their treatment (Papageorgiou et al. 2017).

PWVcf is the gold standard for the measurement of aortic stiffness. It measures the speed of the forward pressure wave that travels along the aorta to the femoral artery and it has been found to be a good predictor of CVD events, such as CHD and stroke (Laurent et al. 2007; Mattace-Raso et al. 2006; Niiranen et al. 2019). Part of the forward pressure that travels is reflected back to the heart when it hits the peripheral arterial branches. AI is a term that represents this wave reflection and it is calculated as (augmentation pressure/pulse pressure $\times$ $100 \%$ ) (Laurent et al. 2007). AI has also been shown to be associated with cardiovascular events, independently of the peripheral pressures (Vlachopoulos et al. 2010).

Researches pertaining to the assessment of these markers among young women, especially among Asian women, are scarce. Such information is needed, in order to establish the use of these markers among young Asian women with risk factor of CVD, for further risk stratification and early management. Thus, the current study was conducted with several objectives. The main aim of the study was to determine the associations between these markers with other CVD risk factors and future CVD risk. The second aim was to determine the associations among the markers themselves.

\section{MATERIALS AND METHODS}

This cross-sectional study obtained ethics approval from the Ethical Research Committee of the Universiti Kebangsaan Malaysia Medical Center (UKMMC), Malaysia (ethics approval code $=$ FF-2014-011). The subjects were recruited by an announcement through flyers, or by a screening program conducted in various places around Kuala Lumpur, which is the capital city of Malaysia. Malaysia is a multiracial country where the majority of the people are Malays, followed by Chinese and Indians. The inclusion criteria were young women that were healthy or having any CVD risk factor. Young was defined as those subjects with an age range from 20 to 40 years old (Institut Penyelidikan Pembangunan Belia Malaysia (2011)). The CVD risk factor was defined as: Hypertension (systolic blood pressure (BP) $\geq 140$ and/ or diastolic $\mathrm{BP} \geq 90 \mathrm{mmHg}$, or those on antihypertensive medication (Bell et al. 2015); abdominal obesity (waist circumference $>80 \mathrm{~cm}$ ) (Tan et al. 2004); smoking, which referred an individual that was still smoking, or to those who had quit smoking for less than 1 year (Negri et al. 1994); dyslipidemia, which were those subjects with total cholesterol $>6.2 \mathrm{mmol} / \mathrm{L}$, or with low density lipoprotein $>4.1 \mathrm{mmol} / \mathrm{L}$, or with high density lipoprotein $<1.3 \mathrm{mmol} / \mathrm{L}$, or triglyceride $>1.7 \mathrm{mmol} / \mathrm{L}$ (Stone et al. 
2005); and a family history of premature CVD (Stone et al. 2005). The exclusion criteria were those with CVD, diabetes mellitus (DM) ((fasting blood sugar $>7 \mathrm{mmol} / \mathrm{L}$ ) (Alberti \& Zimmet 1998)), those with chronic renal, lung, or liver disease, those with chronic inflammation, and pregnant women. The estimated sample size was based on a previous study on CIMT, which required the highest number of sample size compared to CRP, PWVcf, and AI. The mean difference of CIMT between the healthy subjects and with those at risk was $0.04 \mathrm{~mm}$ (Baroncini et al. 2017), with an alpha value of 0.05 , a power value of $80 \%$, and a standard deviation of $0.05 \mathrm{~mm}$. The sample size was calculated based on the formula by Eng (2003). The minimum total number of subjects that must be recruited was 100 (50 per-group). Informed consent was obtained from every subject involved in the study. All of the subjects underwent several measurements for an assessment of the CVD risk factors and vascular markers. They were divided into a healthy group $(\mathrm{HG}, \mathrm{n}=71)$ and those with at least one risk factor of CVD (RG, $n=77)$.

\section{MEASUREMENT OF HEIGHT, WEIGHT,} AND WAIST CIRCUMFERENCE

A digital weighing scale measured the weight and the height was measured by using a wall-mounted stadiometer (SECA, Germany). Waist circumference was measured by using measurements on the bare midriff in a horizontal plane, midway between the lowest rib and the superior border of the iliac crest, using a measuring tape at the end of a normal expiration (Alberti et al. 2006).

\section{MEASUREMENT OF BLOOD PARAMETERS}

Blood $(10 \mathrm{~mL})$ was obtained from the antecubital vein after fasting for more than $6 \mathrm{~h}$ and it was then sent to the Pathology Laboratory UKM Medical Center for the measurements of blood glucose, total cholesterol (TC), high-density lipoprotein (HDL), low-density lipoprotein (LDL), and triglyceride (TG). For the assessments of high sensitivity $\mathrm{C}$ reactive protein (hs-CRP), the blood samples were sent to the Gribbles Laboratory, Kuala Lumpur, Malaysia.

\section{MEASUREMENT OF PWVcf}

The measurements of PWVcf were conducted by using the VICORDER ${ }^{\circledR}$ device (SMT Medical, Würzburg, Germany) on the fasting subjects. The subjects were in a supine position and the BP cuffs were placed at the neck and on the left thigh. They were inflated to $65 \mathrm{mmHg}$ in order to get the corresponding oscillometric signals. The pressure waveforms from the carotid artery and the femoral artery were recorded simultaneously for $30 \mathrm{~s}$. PWV cf was calculated based on the formula $=$ distance $(\mathrm{m}) /$ transit time (s). The distance was measured from the sternal angle to the mid-thigh cuff by using a measuring tape. The transit time was calculated based on the delay between the two recorded pressure waveforms (Aminuddin et al. 2014).

\section{MEASUREMENT OF BRACHIAL AND AORTIC BLOOD PRESSURE AND AUGMENTATION INDEX}

All of the measurements were performed by using the VICORDER ${ }^{\circledR}$ device (SMT Medical, Würzburg, Germany). The cuff was placed on the subject's left arm. The measurements of brachial BP were conducted by the oscillometric technique. The brachial pressure wave was then used to estimate the aortic pressure waveform and the BP by using the generalised transfer function. AI was measured from the aortic pressure waveform by using the following algorithm: $\mathrm{AI}=(($ second systolic peak - first systolic peak)/pulse pressure $\times 100$ ) (Laurent et al. 2007).

\section{MEASUREMENT OF CIMT}

CIMT was obtained from the distance between the lumenintima and the media-adventitia interfaces on the far wall of the left and right common carotid artery (CCA), by using B mode ultrasound (Vivid I, United States) and a linear probe $(10 \mathrm{MHz})$. Only one trained technician performed the procedure and followed the recommendations by the American Society of Echocardiography (ASE) (Stein et al. 2008). The subjects were in a supine position with the head lifted upwards and faced contralateral to the side of the measurement. The measurement was carried out at the smallest diameter of the blood vessel (diastole). An ECG electrode could not be used to estimate the diastolic phase because of technical limitations. CIMT was measured proximal to the carotid bulb within $1 \mathrm{~cm}$. Three readings were taken from both the left and the right CCA, and the average from both sides was taken as the final measurement.

\section{CVD RISK STRATIFICATION}

The short-term CVD risk was calculated based on the 10year Framingham Risk Score (FRS) by using the online risk calculator (https://www.mdcalc.com/framinghamcoronary-heart-disease-risk-score). The parameters that were inserted included gender, age, TC, HDL, SBP, hypertension status, and smoking. The long-term CVD risk was based on the 30-year FRS and was calculated by using the online risk calculator (https://www. framinghamheartstudy.org/risk-functions/cardiovasculardisease/30 year-risk.php). This formula was developed by Pencina et al. (2009). The parameters that were inserted included gender, age, SBP, TC, HDL, smoking status, hypertension status, and DM. The outcomes were a 30-year full CVD risk and a 30-year hard CVD risk.

\section{STATISTICAL ANALYSIS}

The data analysis was conducted by using the Statistical Package for the Social Sciences (SPSS Inc., USA) Version 20. The normality test was performed by using the Kolmogorov-Smirnov test. All of the data is presented as mean $\pm \mathrm{SD}$, except for hs-CRP, which is presented in median values (interquartile range). For hs-CRP, the value was log transformed and this was used for the data analysis. The 
comparison between the groups was conducted by using the independent t-test and when an adjustment for the related confounder was needed, the general linear model univariate was used. The correlation between the parameters was performed by using the Pearson correlation and the partial correlation was used to adjust for age. The independent variables for each vascular marker were determined by using the multiple linear regression analysis. $P$ value $<0.05$ was accepted as significant.

\section{RESULTS}

The clinical characteristics of the subjects are summarised in Table 1. The mean age of the whole of the subjects was $29.97 \pm 5.27$ years old. The risk factor group was older. They had higher BMI, peripheral and central BP, lipid profiles (except for HDL, which was significantly lower), hs-CRP, PWVcf, and AI. The comparisons for AI were adjusted for race, height, and heart rate (HR), as these factors are known to influence AI (Aminuddin et al. 2013). Table 2 shows the short and the long term FRS of the subjects. The RG had a significantly higher score for the 10-year FRS and a higher percentage of the 30-year full and hard CVD risks. Table 3 summarises the correlations between the vascular markers and the other CVD risk factors. PWVcf, AI, and CIMT were correlated with age. PWVcf, AI, and hs-CRP were correlated with most of the CVD risk factors, such as BP and lipid profiles, even after the adjustments for age. PWVcf, AI, and hs-CRP were also significantly correlated with the 10-year FRS. All of the vascular markers had significant associations with the 30-year CVD risk, with PWVcf having the strongest association for both. Table 4 summarises the correlations among the vascular markers. No significant associations were observed between all of the markers. From the multiple linear regression, CIMT was determined by age $(\mathrm{Beta}=0.34, \mathrm{p}<0.01)$ with adjusted $\mathrm{R}^{2}=0.11$. PWVcf was independently determined by the diastolic BP (Beta $=0.46, \mathrm{p}<0.01)$ and age $(\mathrm{Beta}=0.18$, $\mathrm{p}=0.01)$ with adjusted $\mathrm{R}^{2}=0.29$. AI was determined by age (Beta $=0.39, \mathrm{p}<0.01)$, HR (Beta $=-0.33, \mathrm{p}<0.01)$, and LDL (Beta $=0.24, \mathrm{p}<0.01$ ), with adjusted $\mathrm{R}^{2}=0.28$. The hs-CRP values were determined by weight $($ Beta $=0.43, \mathrm{p}<0.01)$ and HDL (Beta $=-0.21, \mathrm{p}=0.01)$ with adjusted $\mathrm{R}^{2}=0.30$.

\section{DISCUSSION}

In this study, CIMT was found to be associated with age and central SBP. The association between CIMT and

TABLE 1. General characteristic of the subjects

\begin{tabular}{lccc}
\hline Parameter & $\begin{array}{c}\text { HG } \\
(\mathrm{n}=71)\end{array}$ & $\begin{array}{c}\text { RG } \\
(\mathrm{n}=77)\end{array}$ & $p$ \\
\hline Age $($ years $)$ & $28.91 \pm 4.93$ & $30.95 \pm 5.40$ & 0.02 \\
Weight $(\mathrm{kg})$ & $52.75 \pm 9.32$ & $69.45 \pm 15.49$ & $<0.01$ \\
Height $(\mathrm{cm})$ & $156.58 \pm 5.12$ & $156.57 \pm 5.41$ & 0.99 \\
BMI $\left(\mathrm{kg} / \mathrm{m}^{2}\right)$ & $21.51 \pm 3.61$ & $28.27 \pm 5.80$ & $<0.01$ \\
HR $(\mathrm{bpm})$ & $70.62 \pm 11.10$ & $71.91 \pm 11.73$ & 0.49 \\
SBP $(\mathrm{mmHg})$ & $116.56 \pm 9.47$ & $124.22 \pm 12.29$ & $<0.01$ \\
DBP $(\mathrm{mmHg})$ & $65.17 \pm 7.38$ & $70.08 \pm 8.41$ & $<0.01$ \\
TC $(\mathrm{mmol} / \mathrm{L})$ & $4.82 \pm 0.66$ & $5.20 \pm 1.10$ & 0.02 \\
TG $(\mathrm{mmol} / \mathrm{L})$ & $0.72 \pm 0.23$ & $1.08 \pm 0.71$ & $<0.01$ \\
HDL $(\mathrm{mmol} / \mathrm{L})$ & $1.64 \pm 0.28$ & $1.45 \pm 0.33$ & $<0.01$ \\
LDL $(\mathrm{mmol} / \mathrm{L})$ & $2.87 \pm 0.60$ & $3.27 \pm 0.99$ & $<0.01$ \\
FBS $(\mathrm{mmol} / \mathrm{L})$ & $4.53 \pm 0.31$ & $4.65 \pm 0.48$ & 0.07 \\
hs-CRP $(\mathrm{mg} / \mathrm{L})$ & $1.29(1.00)$ & $3.34(5.05)$ & $<0.01$ \\
cSBP $(\mathrm{mmHg})$ & $109.08 \pm 8.57$ & $116.53 \pm 12.92$ & $<0.001$ \\
cDBP $(\mathrm{mmHg})$ & $65.17 \pm 7.38$ & $70.41 \pm 8.76$ & $<0.001$ \\
cPP $(\mathrm{mmHg})$ & $44.06 \pm 6.06$ & $47.40 \pm 8.86$ & $<0.01$ \\
CIMT $(\mathrm{mm})$ & $0.47 \pm 0.06$ & $0.47 \pm 0.07$ & 0.52 \\
& & & $0.80^{2}$ \\
PWVcf $\left(\mathrm{ms}{ }^{-1}\right)$ & $6.64 \pm 0.73$ & $7.03 \pm 1.01$ & $<0.01$ \\
& & & $0.04^{2}$ \\
AI $(\%)$ & $13.96 \pm 5.03$ & $16.41 \pm 6.47$ & 0.01 \\
& & & $0.08^{2}$ \\
\hline
\end{tabular}

Data are mean $+\mathrm{SD}$, except for hs-CRP which is in median (interquartile range)

$\mathrm{BMI}=$ Body mass index, $\mathrm{HR}=$ heart rate, $\mathrm{SBP}=$ systolic blood pressure, $\mathrm{DBP}=$ Diastolic blood pressure, $\mathrm{TC}=$ Total cholesterol, TG=Triglyceride, HDL=high density lipoprotein, LDL=low density lipoprotein, FBS=fasting blood sugar, CIMT=average right and left common carotid intima media thickness, $\mathrm{PWVcf}=$ carotid femoral pulse wave velocity, $\mathrm{AI}=$ augmentation indeks, hs-CRP=high sensitivity $\mathrm{C}$-reactive protein

${ }^{2} p$ value after adjustment for the age

\# $p$ value after adjustment for age, race, height and heart rate 
TABLE 2. Short and long term FRS of the subjects

\begin{tabular}{lccc}
\hline & HG & RG & $p$ \\
& $(\mathrm{~N}=71)$ & $(\mathrm{N}=77)$ & $<0.001$ \\
\hline 10-year FRS (score) & $-1.56 \pm 3.39$ & $0.91 \pm 4.72$ & $<0.001$ \\
30-year full CVD risk $(\%)$ & $4.83 \pm 2.74$ & $8.06 \pm 5.36$ & $<0.001$ \\
30-year hard CVD risk $(\%)$ & $2.07 \pm 1.33$ & $3.65 \pm 2.94$ & \\
\hline
\end{tabular}

Data are mean \pm SD

TABLE 3. Correlation between PWVcf, AI, CIMT with other CVD risk factors and FRS

\begin{tabular}{|c|c|c|c|c|}
\hline & CIMT & PWVcf & AI & Lg hs-CRP \\
\hline Age & $0.306 * *$ & $0.313 * *$ & $0.401 * *$ & $0.199 *$ \\
\hline $\begin{array}{l}\text { Height }(\mathrm{cm}) \\
\quad \text { Adjusted for age }\end{array}$ & $\begin{array}{l}0.061 \\
0.088\end{array}$ & $\begin{array}{l}0.018 \\
0.100\end{array}$ & $\begin{array}{c}-0.164 * \\
-0.074\end{array}$ & $\begin{array}{c}-0.013 \\
0.007\end{array}$ \\
\hline $\begin{array}{l}\text { Weight }(\mathrm{kg}) \\
\quad \text { Adjusted for age }\end{array}$ & $\begin{array}{l}0.145 \\
0.068\end{array}$ & $\begin{array}{l}0.094 \\
0.058\end{array}$ & $\begin{array}{r}0.110 \\
-0.001\end{array}$ & $\begin{array}{l}0.522 * * \\
0.493 * *\end{array}$ \\
\hline $\begin{array}{l}\text { BMI }\left(\mathrm{kg} / \mathrm{m}^{2}\right) \\
\quad \text { Adjusted for age }\end{array}$ & $\begin{array}{l}0.144 \\
0.054\end{array}$ & $\begin{array}{l}0.089 \\
0.024\end{array}$ & $\begin{array}{c}0.165^{*} \\
0.028\end{array}$ & $\begin{array}{l}0.549 * * \\
0.512 * *\end{array}$ \\
\hline $\begin{array}{l}\text { WC (cm) } \\
\quad \text { Adjusted for age }\end{array}$ & $\begin{array}{c}0.099 \\
-0.015\end{array}$ & $\begin{array}{l}0.148 \\
0.086\end{array}$ & $\begin{array}{c}0.183^{*} \\
0.064\end{array}$ & $\begin{array}{l}0.513 * * \\
0.464 * *\end{array}$ \\
\hline $\begin{array}{l}\text { SBP (mmHG) } \\
\quad \text { Adjusted for age }\end{array}$ & $\begin{array}{l}0.179 \\
0.111\end{array}$ & $\begin{array}{l}0.418 * * \\
0.418 * *\end{array}$ & $\begin{array}{c}0.011 \\
-0.103\end{array}$ & $\begin{array}{c}0.223 * * \\
0.166\end{array}$ \\
\hline $\begin{array}{l}\mathrm{DBP}(\mathrm{mmHg}) \\
\quad \text { Adjusted for age }\end{array}$ & $\begin{array}{l}0.138 \\
0.060\end{array}$ & $\begin{array}{l}0.513 * * \\
0.551 * *\end{array}$ & $\begin{array}{l}-0.006 \\
-0.134\end{array}$ & $\begin{array}{c}0.243 * * \\
0.190 *\end{array}$ \\
\hline $\begin{array}{l}\text { HR (bpm) } \\
\quad \text { Adjusted for age }\end{array}$ & $\begin{array}{l}0.053 \\
-0.011\end{array}$ & $\begin{array}{l}0.323 * * \\
0.367 * *\end{array}$ & $\begin{array}{l}-0.278 * * \\
-0.391 * *\end{array}$ & $\begin{array}{l}0.058 \\
0.010\end{array}$ \\
\hline $\begin{array}{l}\text { CSBP (mmHg) } \\
\text { Adjusted for age }\end{array}$ & $\begin{array}{c}0.214^{*} \\
0.123\end{array}$ & $\begin{array}{l}0.450 * * \\
0.425 * *\end{array}$ & $\begin{array}{l}0.198 * \\
-0.031\end{array}$ & $\begin{array}{c}0.214 * * \\
0.212 *\end{array}$ \\
\hline $\begin{array}{l}\mathrm{CDBP}(\mathrm{mmHg}) \\
\text { Adjusted for age }\end{array}$ & $\begin{array}{l}0.138 \\
0.060\end{array}$ & $\begin{array}{c}-0.021 \\
-0.207 *\end{array}$ & $\begin{array}{c}0.256^{* *} * \\
0.190 *\end{array}$ & $\begin{array}{c}0.256^{* *} \\
0.190^{*}\end{array}$ \\
\hline $\begin{array}{l}\mathrm{TC}(\mathrm{mmol} / \mathrm{L}) \\
\text { Adjusted for age }\end{array}$ & $\begin{array}{l}0.093 \\
0.027\end{array}$ & $\begin{array}{c}0.174 * \\
0.251 * *\end{array}$ & $\begin{array}{l}0.089 \\
0.040\end{array}$ & $\begin{array}{l}0.089 \\
0.040\end{array}$ \\
\hline $\begin{array}{l}\text { TG (mmol/L) } \\
\text { Adjusted for age }\end{array}$ & $\begin{array}{c}0.055 \\
-0.051\end{array}$ & $\begin{array}{l}0.117 \\
0.048\end{array}$ & $\begin{array}{c}0.277 * * \\
0.182\end{array}$ & $\begin{array}{c}0.277 * * \\
0.182\end{array}$ \\
\hline $\begin{array}{l}\text { HDL (mmol/L) } \\
\text { Adjusted for age }\end{array}$ & $\begin{array}{c}-0.026 \\
0.002\end{array}$ & $\begin{array}{l}-0.118 \\
0.027\end{array}$ & $\begin{array}{l}-0.404 * * \\
-0.351 * *\end{array}$ & $\begin{array}{l}-0.404 * * \\
-0.351 * *\end{array}$ \\
\hline $\begin{array}{l}\mathrm{LDL}(\mathrm{mmol} / \mathrm{L}) \\
\text { Adjusted for age }\end{array}$ & $\begin{array}{l}0.088 \\
0.034\end{array}$ & $\begin{array}{c}0.209 * \\
0.263 * *\end{array}$ & $\begin{array}{c}0.166^{* *} \\
0.116\end{array}$ & $\begin{array}{c}0.166^{* *} \\
0.116\end{array}$ \\
\hline $\begin{array}{l}\text { FBS (mmol/L) } \\
\text { Adjusted for age }\end{array}$ & $\begin{array}{l}0.112 \\
0.047\end{array}$ & $\begin{array}{l}0.160 \\
0.099\end{array}$ & $\begin{array}{l}0.079 \\
0.042\end{array}$ & $\begin{array}{l}0.079 \\
0.042\end{array}$ \\
\hline 10-year FRS (score) & 0.144 & $0.326 * *$ & $0.287 * *$ & $0.287 * *$ \\
\hline 30-year full CVD risk (\%) & $0.305^{* *}$ & $0.379 * *$ & $0.330 * *$ & $0.330 * *$ \\
\hline 30-year hard CVD risk (\%) & $0.303 * *$ & $0.341 * *$ & $0.331 * *$ & $0.305^{* *}$ \\
\hline
\end{tabular}

Value are Pearson's correlation $r$

$\mathrm{BMI}=$ Body mass index, $\mathrm{HR}=$ heart rate, $\mathrm{SBP}=$ systolic blood pressure, $\mathrm{DBP}=$ Diastolic blood pressure, $\mathrm{TC}=$ Total cholesterol, $\mathrm{TG}=$ Triglyceride, $\mathrm{HDL}=$ high density lipoprotein, LDL=low density lipoprotein, FBS=fasting blood sugar, CIMT=average right and left common carotid intima media thickness, $\mathrm{PWV}$ cf=carotid femoral pulse wave velocity, $\mathrm{AI}=$ augmentation indeks, hs-CRP=high sensitivity $\mathrm{C}$-reactive protein, $\mathrm{FRS}=$ Framingham risk score $* p<0.05, * * p<0.01$

central SBP diminished after the adjustments for age were carried out. The lack of association between CIMT and the other conventional CVD risk factors among the young subjects has also been supported by $\mathrm{Ku}$ et al. (2011). In that research, CIMT was not associated with any CVD risk factors among 101 young women with a previous history of normal pregnancy or gestational DM. In contrast, the study by Tarim et al. (2006) found that among young normal pregnant women or diabetics, CIMT was associated with BMI. Another study by Wu et al. (2016) found that among 
TABLE 4. Correlations among vascular markers

\begin{tabular}{lcccc}
\hline & CIMT & PWVcf & AI & Lg hs-CRP \\
\hline CIMT & 1 & 0.146 & 0.071 & 0.077 \\
$\quad$ Adjusted for age & & 0.066 & -0.034 & 0.011 \\
PWVcf & & 1 & 0.069 & 0.122 \\
$\quad$ Adjusted for age & & & -0.107 & 0.156 \\
AI $\quad 0.071$ & & 1 & 0.150 \\
$\quad$ Adjusted for age & -0.034 & 0.122 & & 0.096 \\
Lg hs-CRP & 0.077 & 0.158 & & 1 \\
$\quad$ Adjusted for age & 0.011 & &
\end{tabular}

Value are Pearson's correlation $r$

CIMT=average right and left common carotid intima media thickness, $\mathrm{PWVcf}=$ carotid femoral pulse wave velocity, $\mathrm{AI}=$ augmentation indeks, hs-CRP=high sensitivity $\mathrm{C}$-reactive protein

1579 subjects aged between 40-74 years old, there were correlations between CIMT, age, BMI, WC, BP, and the lipid profiles. A study by Nafikudin et al. (2003) showed that CIMT was associated with BMI and waist-hip ratios among familial hypercholesterolaemic patients (mean age: 42.8 \pm 12.1 years). The discrepancies between the current study and these other authors may be due to the different targeted subjects and the age of the subjects.

For PWVcf, this study found an association with BP, central BP, HR, and TC after adjustments for age. However, only age and DBP were the independent predictors for PWVcf.A research that was carried out on East Asian people where the prevalence of atherosclerosis was low, found that arterial stiffness increased with age by approximately 0.1 m/s per year (Avolio et al. 1983; Cecelja \& Chowienczyk 2012). Age was also an important factor for arterial stiffness as measured by using finger photoplethysmography (PPG) (Yousef et al. 2012). Aortae contain more elastin fibres when compared to peripheral blood vessels. An increased age will cause the elastin fibres and the elastin-collagen ratio to be reduced, thus increasing the arterial stiffness (Choo et al. 2014). Nurnberger et al. (2003) also found a significant association between PWV and DBP among young men. Nurnberger et al. (2003) suggested that among the young men, due to a low PWV, the reflection wave arrived at the aorta during diastole and this increased the DBP. This may explain the significant association between PWV and DBP and not with the other BP components.

In this study, the multiple linear regression analysis showed that AI was associated with age, HR (negative association), and LDL. This was in line with a previous study by Janner et al. (2012) that involved 3432 men and women with an age range of between 20 and 97 years old. The multiple linear regression was performed according to gender and age, with the less than 60-year olds and the more than 60 -year olds. For the subjects less than 60 years old, age, height, weight, HR, BP, and TC were the independent predictors for AI. Another study by Wilkinson et al. (2002) also found that AI was associated with age, height, MAP, HR, LDL, and male gender.

For hs-CRP, this study found that it was independently determined by weight and HDL (negative association). CRP was also significantly associated with total body fat among adolescent girls of independent age and socioeconomic status (Mirhosseini et al. 2012). The association between CRP and obesity measurements may be due to the presence of adipose tissue that secretes varieties of hormones and cytokines that stimulate CRP secretions. Obesity is also related to accumulations of free fatty acid that activates proinflammatory serine kinase cascades, such as I $\mathrm{B}$ kinase and c-Jun $\mathrm{N}$-terminal kinase. These cascades enhance the secretion of the cytokines interleukin-6 (IL-6) and tumour necrosis factor-alpha (TNF-alpha) from the adipose tissue, which influences the liver to secret CRP (Choi et al. 2013). The associations between the vascular markers and the future short and long-term CVD risks among young women are lacking. In this study, it was observed that PWVcf, AI, and CRP were associated with the short-term CVD risk. This has been supported by previous studies for PWV (Norhayati et al. 2015), AI (Aminuddin et al. 2014), and CRP (Matsushita et al. 2007). No association was observed between CIMT and the short term FRS. In contrast, the study by Özdemir et al. (2013) observed that there was an association between CIMT and FRS among normal subjects and subjects with an obstructive sleep apnoea. These discrepancies in the results may be due to the different subjects' background. For the long-term CVD risk, all of the vascular markers had a significant association with the 30-year CVD risk. The associations were moderate for PWVcf, AI, and CRP and weak for CIMT. The current study has added this information to the literature since the association between the vascular markers and the longterm CVD risks among young women subjects are scarce.

This study found that no association was observed between CIMT, PWVcf, and AI. This finding is in contrast with the study by Pflederer et al. (2016), which found that there was an association between CIMT and PWV among hypertensive subjects aged $61.7 \pm 9.5$ years old, with more severe CVD risk factors, such as being on antihypertensive medication, having DM, and with chronic renal failure. The current findings were in line with a previous study by Koivistoinen et al. (2012). The researchers conducted a study among 1754 young subjects aged 30-45 years old and 336 older subjects aged 46-76 years old. The 
researchers found that there was no association between CIMT and PWV among the young subjects, but there was an association among the older subjects. Another study among healthy and diabetic patients observed that there was an association between CIMT and AI (Gomez-Marcos et al. 2011). However, among the healthy subjects, this association became insignificant after the adjustments for age, gender, and heart rate, but remained significant among the diabetic subjects. In general, no association was observed between CIMT, PWVcf, and AI among the young subjects with CVD risk factors, or the healthy subjects, which is in line with a recent review by Salamt et al. (2018). In the young subjects, changes in CIMT due to $\mathrm{CVD}$ risk factors may be minimal and may take a longer time to develop. CIMT also reflexes a different entity when compared to PWVcf and AI, whereby CIMT represents the structure of the blood vessels, while PWVcf and AI are more on a vascular function. Thus, these parameters may not have any association, especially in the early course of a risk factor.

In this study, no association was observed between CIMT and CRP. In contrast, the study by Parildal et al. (2013) on healthy and pre-diabetic subjects aged 40 years and above found a significant association. Another study by Trindade et al. (2012) also found a significant association, which involved 116 hypertensive women aged 40-60 years old. However, another study by Kurkowska-Jastrzebska et al. (2016) found nearly similar findings to the current study. That study investigated the association between CIMT and CRP among 75 healthy subjects, 79 ischemic stroke subjects, and 37 subjects with myocardial infarction (MI). The subjects' age ranged from 55 to 85 years old. They found that significant associations were observed only among MI patients. These discrepancies in the results of the previous researches may be due to the older ages, the severity of the CVD risk factors, and the higher levels of CRP and CIMT when compared to the current study. Furthermore, several studies have reported that a CIMT level less than $1.1 \mathrm{~mm}$ was not related to atherosclerosis, but was more associated with a thickening of the intima, in response to the physiological variations, such as the changes in blood flow, shear stress, and the tensile stress of the artery (Bots et al. 1997). This may also explain why CIMT and CRP were not having any correlations since the mean CIMT level in this study was $0.47 \pm 0.07 \mathrm{~mm}$.

No associations were observed between CRP, PWVcf, and $\mathrm{AI}$ in this study, although all of the parameters were significantly increased with the presence of the CVD risk factors. This was in line with previous studies (Aminuddin et al. 2014; Tomiyama et al. 2004). A study by Aminuddin et al. (2014) involved young men that were either healthy or having any CVD risk factor. Tomiyama et al. (2004) involved 2668 subjects with an age that ranged from 3074 years old and they found no associations when using multiple linear regression. They suggested that CRP, PWVcf, and AI were different CVD predictors and were independent of each other. Besides that, Arnold et al. (2017) suggested that an association between inflammation and arterial stiffness would be more significant for the long-term follow-up when compared to the short term. This was supported by a study that involved 16 and 20year olds that when followed up, showed that CRP was a predictor for PWV (Johansen et al. 2012; McEniery et al. 2010), but the short-term study was not able to elicit the relationship (Tomiyama et al. 2010; van Bussel et al. 2011). In contrast, several other studies have found associations between CRP, PWV, and AI (Kullo et al. 2005; Nakhai-Pour et al. 2007; Yasmin et al. 2004). The study by NakhaiPour et al. (2007) involved older subjects with CVD, DM, and on medication, while the study by Kullo et al. (2005) involved adult subjects with a mean age of $59.6 \pm 10.2$ years old, asymptomatic of CVD. Again, the difference in ages and the severity of the risk factors may account for the discrepancies in the results.

The strength of this study was that the researchers investigated the associations between the vascular markers and the long term FRS, which was not carried out in previous studies. The use of the long-term FRS has added meaningful information, as it provides a longer-term risk prediction, especially among young women who generally have a low risk that is based on the 10-year FRS. The accumulation of risk factors since young and with an increasing life expectancy suggests the need for long-term risk assessments (Pencina et al. 2009). This study also concurrently measured a thorough assessment of the vascular damage, including blood parameters (CRP), vascular functions (PWVcf and AI), and the imaging technique (CIMT), whereby a limited study had been conducted previously.

There are several limitations to this study. Firstly, this was a cross-sectional study, therefore, the causality between the vascular markers and the other variables were not strongly established. Secondly, the majority of the subjects consisted of Malays and Chinese only, which did not truly represent the multiracial Malaysian population. Lastly, the researchers did not take into account the menstrual history of the subjects for the assessment of PWVcf, which may have affected the results. The previous study found that changes in the hormone level during the menstrual cycle affected the PWVcf (Aminuddin et al. 2018).

\section{CONCLUSION}

In conclusion, among young Asian women with CVD risk factors, CIMT, PWVcf, AI, and hs-CRP can be used to assess the risk of future CVD. The lack of association between the markers themselves suggests that every marker reflects a different entity and they should be measured independently for a thorough vascular assessment.

\section{ACKNOWLEDGEMENTS}

The investigators would like to thank Aini Farzana Zulkefli, Norliza Saari, and Firdaus Azmi for their valuable support. This project was funded by a GUP-2017-096 grant. 


\section{REFERENCES}

Alberti, K.G.M.M. \& Zimmet, P.F. 1998. Definition, diagnosis and classification of diabetes mellitus and its complications. Part 1: diagnosis and classification of diabetes mellitus. Provisional report of a WHO consultation. Diabetic Medicine 15(7): 539-553.

Alberti, K.G.M.M., Zimmet, P. \& Shaw, J. 2006. Metabolic syndrome-a new world-wide definition. A consensus statement from the International Diabetes Federation. Diabetic Medicine 23(5): 469-480.

Aminuddin, A., Chellappan, K., Maskon, O., Zakaria, Z., A. Karim, A., Ngah, W.Z. \& Mohd Nordin, N.M. 2014. Augmentation index is a better marker for cardiovascular risk in young Malaysian males. A comparison of involvement of pulse wave velocity, augmentation index and C-Reactive Protein. Saudi Medical Journal 35(2): 138-146.

Aminuddin,A., Hakim, L.A., Chan, S.Y., Elyatulnadia, S., Akma, H.H., Afifa, N.S.R., Ugusman, A. \& Chellappan, C. 2018. The changes of aortic stiffness during normal menstrual cycle. Medicine and Health 13(1): 117-129.

Aminuddin, A., Zakaria, Z., Fuad, A.F., Kamsiah, J., Othman, F., Das, S., Kamisah, Y., Qodriyah, H.S., Jubri, Z., Nordin, N.A.M. \& Ngah, W.Z. 2013. High $\mathrm{C}$ reactive protein associated with increased pulse wave velocity among urban men with metabolic syndrome in Malaysia. Saudi Medical Journal 34(3): 266-275.

Arnold, N., Gori, T., Schnabel, R.B., Schulz, A., Prochaska, J.H., Zeller, T., Binder, H., Pfeiffer, N., Beutel, M., Espinola-Klein, C. \& Lackner, K.J. 2017. Relation between arterial stiffness and markers of inflammation and hemostasis-data from the population-based Gutenberg Health Study. Scientific Reports 7(1): 6346.

Avolio, A.P., Chen, S.G., Wang, R.P., Zhang, C.L., Li, M.F. \& O'Rourke, M.F. 1983. Effects of aging on changing arterial compliance and left ventricular load in a Northern Chinese urban community. Circulation 68(1): 50-58.

Baroncini, L.A.V., Sylvestre, L.D.C., Baroncini, C.V. \& Filho, R.P. 2017. Assessment of carotid intima-media thickness as an early marker of vascular damage in hypertensive children. Arquivos Brasileiros de Cardiologia 108(5): 452-457.

Bell, K., Twiggs, J. \& Olin, B.R. 2015. Hypertension: The silent killer: Updated JNC-8 guideline recommendations. Alabama Pharmacy Association https://cdn.ymaws.com/www.aparx. org/resource/resmgr/CEs/CE_Hypertension_The_Silent_K. pdf.

Bots, M.L., Hofman, A. \& Grobbee, D.E. 1997. Increased common carotid intima-media thickness: Adaptive response or a reflection of atherosclerosis? Findings from the Rotterdam Study. Stroke 28(12): 2442-2447.

Cecelja, M. \& Chowienczyk, P. 2012. Role of arterial stiffness in cardiovascular disease. Journal of the Royal Society of Medicine Cardiovascular Disease 1(4). doi: 10.1258/ cvd.2012.012016.

Chambless, L.E., Folsom, A.R., Clegg, L.X., Sharrett, A.R., Shahar, E., Nieto, F.J., Rosamond, W.D. \& Evans, G. 2000. Carotid wall thickness is predictive of incident clinical stroke: The Atherosclerosis Risk in Communities (ARIC) study. American Journal of Epidemiology 151(5): 478-487.

Chambless, L.E., Heiss, G., Folsom, A.R., Rosamond, W., Szklo, M., Sharrett, A.R. \& Clegg, L.X. 1997. Association of coronary heart disease incidence with carotid arterial wall thickness and major risk factors: The Atherosclerosis Risk in Communities (ARIC) Study, 1987-1993. American Journal of Epidemiology 146(6): 483-494.
Choi, J., Joseph, L. \& Pilote, L. 2013. Obesity and C-reactive protein in various populations: A systematic review and metaanalysis. Obesity Reviews 14(3): 232-244.

Choo, J., Shin, C., Barinas-Mitchell, E., Masaki, K., Willcox, B.J., Seto, T.B., Ueshima, H., Lee, S., Miura, K., Venkitachalam, L., Mackey, R.H., Evans, R.W., Kuller, L.H., Sutton-Tyrrell, K. \& Sekikawa, A. 2014. Regional pulse wave velocities and their cardiovascular risk factors among healthy middle-aged men: A cross-sectional population-based study. BioMed Central Cardiovascular Disorders 14(1): 5. doi:10.1186/1471-2261-14-5.

Comşa, H., Zdrenghea, D., Man, S.C. \& Pop, D. 2018. The role of novel atherosclerosis markers in peripheral artery disease: Is there a gender difference? Cardiovascular Journal of Africa 29(5): 322-330.

Eng, J. 2003. Sample size estimation: How many individuals should be studied? Radiology 227(2): 309-313.

Faustino, R.P.L., Luis, L.M., Amanda, K., Peter, C. \& Hugh, S.T. 2010. Gender differences in cardiovascular disease: Hormonal and biochemical influences. Reproductive Sciences 17(6): 511-531.

Goff, D.C., Lloyd-Jones, D.M., Bennett, G., Coady, S. D’Agostino, R.B., Gibbons, R., Greenland, P., Lackland, D.T., Levy, D., O’Donnell, C.J. \& Robinson, J.G. 2014. 2013 ACC/ AHA guideline on the assessment of cardiovascular risk: A report of the American College of Cardiology/American Heart Association Task Force on Practice Guidelines. Journal of the American College of Cardiology 63(25 Part B): 29352959.

Gómez-Marcos, M.Á., Recio-Rodríguez, J.I., Patino-Alonso, M.C., Agudo-Conde, C., Gómez-Sánchez, L., RodríguezSánchez, E., Martin-Cantera, C. \& García-Ortiz, L. 2011. Relationship between intima-media thickness of the common carotid artery and arterial stiffness in subjects with and without type 2 diabetes: A case-series report. Cardiovascular Diabetology 10(1): 3. doi: 10.1186/1475-2840-10-3.

Greenland, P., Alpert, J.S., Beller, G.A., Benjamin, E.J., Budoff, M.J., Fayad, Z.A., Foster, E., Hlatky, M.A., Hodgson, J.M., Kushner, F.G. \& Lauer, M.S. 2010. 2010 ACCF/ AHA guideline for assessment of cardiovascular risk in asymptomatic adults: A report of the American College of Cardiology Foundation/American Heart Association task force on practice guidelines developed in collaboration with the American Society of Echocardiography, American Society of Nuclear Cardiology, Society of Atherosclerosis Imaging and Prevention, Society for Cardiovascular Angiography and Interventions, Society of Cardiovascular Computed Tomography, and Society for Cardiovascular. Journal of the American College of Cardiology 56(25): e50-e103.

Griselli, M., Herbert, J., Hutchinson, W.L., Taylor, K.M., Sohail, M., Krausz, T. \& Pepys, M.B. 1999. C-reactive protein and complement are important mediators of tissue damage in acute myocardial infarction. Journal of Experimental Medicine 190(12): 1733-1740.

Hamidon, B.B., Sapiah, S., Nawawi, H. \& Raymond, A.A. 2004 The prognostic value of C-reactive protein (CRP) levels in patients with acute ischaemic stroke. Medical Journal of Malaysia 59(5): 631-637.

Institut Penyelidikan Pembangunan Belia Malaysia. 2011. Indeks Belia Malaysia 2011. https://www.ippbm.gov.my/dokumen/ IBM2011.pdf.

Janner, J.H., Godtfredsen, N.S., Ladelund, S., Vestbo, J. \& Prescott, E. 2012. The association between aortic 
augmentation index and cardiovascular risk factors in a large unselected population. Journal of Human Hypertension 26(8): 476-484.

Johansen, N.B., Vistisen, D., Brunner, E.J., Tabák,A.G., Shipley, M.J., Wilkinson, I.B., McEniery, C.M., Roden, M., Herder, C., Kivimäki, M.\& Witte, D.R. 2012. Determinants of aortic stiffness: 16-year follow-up of the Whitehall II study. PLoS ONE 7(5): e37165.

Koivistoinen, T., Virtanen, M., Hutri-Kähönen, N., Lehtimäki, T., Jula, A., Juonala, M., Moilanen, L., Aatola, H., Hyttinen, J., Viikari, J.S., Raitakari, O.T. \& Kahonen, M. 2012. Arterial pulse wave velocity in relation to carotid intima-media thickness, brachial flow-mediated dilation and carotid artery distensibility: The cardiovascular risk in Young Finns Study and the Health 2000 Survey. Atherosclerosis 220(2): 387-393.

Ku, Y.H., Choi, S.H., Lim, S., Cho, Y.M., Park, Y.J., Park, K.S., Kim, S.Y. \& Jang, H.C. 2011. Carotid intimal-medial thickness is not increased in women with previous gestational diabetes mellitus. Diabetes \& Metabolism Journal 35(5): 497-503.

Kullo, I.J., Seward, J.B., Bailey, K.R., Bielak, L.F., Grossardt, B.R., Sheedy, P.F., Peyser, P.A. \& Turner, S.T., 2005. $\mathrm{C}$-reactive protein is related to arterial wave reflection and stiffness in asymptomatic subjects from the community. American Journal of Hypertension 18(8): 1123-1129.

Kurkowska-Jastrzębska, I., A Karliński, M., BłażejewskaHyżorek, B., Sarzyńska-Długosz, I., Filipiak, K.J. \& Członkowska, A. 2016. Carotid intima media thickness and blood biomarkers of atherosclerosis in patients after stroke or myocardial infarction. Croatian Medical Journal 57(6): 548-557.

Laurent, S., Cockcroft, J., Van Bortel, L., Boutouyrie, P., Giannattasio, C., Hayoz, D., Pannier, B., Vlachopoulos, C., Wilkinson, I. \& Struijker-Boudier, H. 2007. Abridged version of the expert consensus document on arterial stiffness. Artery Research 1(1): 2-12.

Maas, A.H.E.M. \& Appleman, Y.E.A. 2010. Gender differences in coronary heart disease. Netherlands Heart Journal 18(12): 598-602.

Matsushita, K., Yatsuya, H., Tamakoshi, K., Yang, P.O., Otsuka, R., Wada, K., Mitsuhashi, H., Hotta, Y., Kondo, T., Murohara, T. \& Toyoshima, H. 2007. High-sensitivity C-reactive protein is quite low in Japanese men at high coronary risk. Circulation Journal 71(6): 820-825

Mattace-Raso, F., Tischa, J.M., Cammen, V.D., Hofman, A., Popele, N.M., Bos, M.L., Maarten, A.D.H., Asmar, R., Reneman, R.S., Hoeks, A.P.G., Breteler, M.M.B.\& Witteman, J.C.M. 2006. Arterial stiffness and risk of coronary heart disease and stroke: The Rotterdam Study. Circulation 113: 657-663.

McEniery, C.M., Spratt, M., Munnery, M., Yarnell, J., Lowe, G.D., Rumley, A., Gallacher, J., Ben-Shlomo, Y., Cockcroft, J.R. \& Wilkinson, I.B. 2010. An analysis of prospective risk factors for aortic stiffness in men: 20-year follow-up from the Caerphilly prospective study. Hypertension 56(1): 36-43.

Mirhosseini, N.Z., Shahar, S., Ghayour-Mobarhan, M., Parizadeh, M.R., Yusoff, N.A.M. \& Shakeri, M.T. 2012. Body fat distribution and its association with cardiovascular risk factors in adolescent Iranian girls. Iranian Journal of Pediatrics 22(2): 197-204.

Mulders, T.A., Sivapalaratnam, S., Stroes, E.S., Kastelein, J.J., Guerci, A.D. \& Pinto-Sietsma, S.J. 2012. Asymptomatic individuals with a positive family history for premature coronary artery disease and elevated coronary calcium scores benefit from statin treatment: A post hoc analysis from the St. Francis Heart Study. JACC: Cardiovascular Imaging 5(3): 252-260.

Nafikudin, M., Nawawi, H., Muid, S., Annuar, R., Yusoff, K. \& Khalid, B.A. 2003. Measurement of intima-media thickness of common carotid arteries using ultrasound in patients with familial and non-familial hypercholesterolaemia and correlation of intima-media thickness to obesity. The Medical Journal of Malaysia 58(5): 647-652.

Nakhai-Pour, H.R., Grobbee, D.E., Bots, M.L., Muller, M. \& Van Der Schouw, Y.T. 2007. C-reactive protein and aortic stiffness and wave reflection in middle-aged and elderly men from the community. Journal of Human Hypertension 21(2): 949-955.

Negri, E., La Vecchia, C., D’Avanzo, B., Nobili, A. \& La Malfa, R.G. 1994. Acute myocardial infarction: Association with time since stopping smoking in Italy. GISSI-EFRIM Investigators. Gruppo Italiano per lo Studio della Sopravvivenza nell'Infarto. Epidemiologia dei Fattori di Rischio dell'Infarto Miocardico. Journal of Epidemiology \& Community Health 48(2): 129-133.

Niiranen, T.J., Kalesan, B., Mitchell, G.F. \& Vasan, R.S 2019. Relative contributions of pulse pressure and arterial stiffness to cardiovascular disease: The Framingham Heart Study. Hypertension 73(3): 712-717.

Norhayati, M.N., Hanif, I. \& Rasool, A.H. 2015. Association between carotid-femoral pulse wave velocity with cardiovascular disease risk factors and Framingham coronary disease risk prediction score among hypertensive patients in primary health care. International Journal of Collaborative Research on Internal Medicine \& Public Health 7(4): 72-81.

Nürnberger, J.O.S.A.D.S., Dammer, S., Saez, A.O., Philipp, T. \& Schäfers, R.F. 2003. Diastolic blood pressure is an important determinant of augmentation index and pulse wave velocity in young, healthy males. Journal of Human Hypertension 17(3): 153-158

Özdemir, C., Conkbayır, I., Kuru, A., Fırat, H., Sökücü, S.N., Dalar, L., Ergün, R., Uzunmehmetoğlu, Ç.P., Ergün, D. $\&$ Ardic, S. 2013. Correlation between the intima-media thickness and Framingham risk score in patients with sleep apnea syndrome. Journal of Thoracic Disease 5(6): 751-757.

Papageorgiou, N., Briasoulis, A., Androulakis, E. \& Tousoulis D. 2017. Imaging subclinical atherosclerosis: Where do we stand? Current Cardiology Reviews 13(1): 47-55.

Pencina, M.J., D’Agostino, R.B., Larson, M.G., Massaro, J.M. \& Vasan, R.S. 2009. Predicting the 30-year risk of cardiovascular disease. Circulation 119(24): 3078-3084.

Pflederer, M.C., Long, C.S., Beaty, B., Havranek, E.P., Mehler, P.S., Keniston, A. \& Krantz, M.J. 2016. Longitudinal changes in vascular risk markers and mortality rates among a Latino population with hypertension. Texas Heart Institute Journal 43(2): 131-136.

Ridker, P.M., Rifai, N., Rose, L., Buring, J.E. \& Cook, N.R. 2002. Comparison of C-reactive protein and low-density lipoprotein cholesterol levels in the prediction of first cardiovascular events. The New England Journal of Medicine 347: 1557-1565.

Ridker, P.M., Buring, J.E., Rifai, N. \& Cook, N.R. 2007 Development and validation of improved algorithms for the assessment of global cardiovascular risk in women. Journal of American Medical Association 297: 611-619.

Robert, A.W., Enrico, C., Eventhia, D.K., Anuja, D., Hector, F.E.M., Walter, F., Rogerio, L., Robert, J.N., Evelyn, T. 
\& Daniel, A.D. 2010. Assessment of cardiovascular risk and prevention of cardiovascular disease in women with Polycystic Ovary Syndrome: A consensus statement by the androgen excess and Polycystic Ovary Syndrome (AEPCOS) Society. The Journal of Clinical Endocrinology \& Metabolism 95(5): 2038-2049.

Salamt, N., Aminuddin, A., Ugusman, A. \& Zulkefli, A.F. 2018. Association between pulse wave velocity with other vascular markers and inflammation among young adults: An evidencebased review. Sains Malaysiana 47(10): 2455-2461.

Shah, S.A., Jing, L., Khalid, M.S., Najid, F., Haniff, I.S., Ghazi, A.M., Nor, I.F.M., Ali, R.M. \& Ngah, W.Z.W. 2015. Prevalence and risk factors of premature coronary artery disease: A comparative cross-sectional study between two time frames in Malaysia. Malaysian Journal of Public Health Medicine 15: 157-166.

Stein, J.H., Korcarz, C.E., Hurst, T., Lon, E., Kendall, C.B., Mohler, E.R., Najjar, S.S., Rembold, C.M. \& Post, W.S. 2008. Use of carotid ultrasound to identify subclinical vascular disease and evaluate cardiovascular disease risk: A consensus statement from the American Society of Echocardiography Carotid Intima-Media Thickness Task Force endorsed by the Society for Vascular Medicine. Journal of the American Society of Echocardiography 21(2): 93-111.

Stone, N.J., Bilek, S. \& Rosenbaum, S. 2005. Recent national cholesterol education program adult treatment panel III update: Adjustments and options. The American Journal of Cardiology 96(4): 53-59.

Talari, H.R., Poladchang, S., Hamidian, Y., Samimi, M., Gilasi, H.R., Ebrahimi, F.A. \& Asemi, Z. 2018. The effects of Omega-3 and Vitamin E co-supplementation on carotid intima-media thickness and inflammatory factors in patients with Polycystic Ovary Syndrome. Oman Medical Journal 33(6): 473-479.

Tan, C.E., Ma, S., Wai, D., Chew, S.K. \& Tai, E.S. 2004. Can we apply the National Cholesterol Education Program Adult Treatment Panel definition of the metabolic syndrome to Asians? Diabetes Care 27(5): 1182-1186.

Tarim, E., Yigit, F., Kilicdag, E., Bagis, T., Demircan, S., Simsek, E., Haydardedeoglu, B. \& Yanik, F. 2006. Early onset of subclinical atherosclerosis in women with gestational diabetes mellitus. Ultrasound in Obstetrics \& Gynecology 27(2): 177-182.

Tomiyama, H., Arai, T., Koji, Y., Yambe, M., Hirayama, Y., Yamamoto, Y. \& Yamashina, A. 2004. The relationship between high-sensitive C-reactive protein and pulse wave velocity in healthy Japanese men. Atherosclerosis 174(2): 373-377.

Tomiyama, H., Hashimoto, H., Tanaka, H., Matsumoto, C., Odaira, M., Yamada, J., Yoshida, M., Shiina, K., Nagata, M. \& Yamashina,A. 2010. Continuous smoking and progression of arterial stiffening: A prospective study. Journal of the American College of Cardiology 55(18): 1979-1987.

Touboul, P.J., Hennerici, M.G., Meairs, S., Adams, H., Amarenco, P., Bornstein, N., Csiba, L., Desvarieux, M., Ebrahim, S., Hernandez, R.H. \& Jaff, M. 2012. Mannheim carotid intimamedia thickness and plaque consensus (2004-2006-2011). Cerebrovascular Disease 34(4): 290-296.
Trindade, M., Martucci, R.B., Burlá, A.K., Oigman, W., Neves, M.F. \& Araújo, D.V. 2012. Evaluation of clinical variables associated with increased carotid intima-media thickness in middle-aged hypertensive women. International Journal of Hypertension 2012: 257501.

van Bussel, B.C., Schouten, F., Henry, R.M., Schalkwijk, C.G., de Boer, M.R., Ferreira, I., Smulders, Y.M., Twisk, J.W. \& Stehouwer, C.D. 2011. Endothelial dysfunction and lowgrade inflammation are associated with greater arterial stiffness over a 6-year period. Hypertension 58(4): 588-595.

Vlachopoulos, C., Aznaouridis, K., O'rourke, M.F., Safar, M.E., Baou, K.\& Stefanadis, C. 2010. Prediction of cardiovascular events and all-cause mortality with central haemodynamics: A systematic review and meta-analysis. European Heart Journal 31(15): 1865-1871.

Wilkinson, I.B., Prasad, K., Hall, I.R., Thomas, A., MacCallum, H., Webb, D.J., Frenneaux, M.P. \& Cockcroft, J.R. 2002. Increased central pulse pressure and augmentation index in subjects with hypercholesterolemia. Journal of the American College of Cardiology 39(6): 1005-1011.

Wu, T.W., Hung, C.L., Liu, C.C., Wu, Y.J., Wang, L.Y.\& Yeh, H.I. 2016. Associations of cardiovascular risk factors with carotid intima-media thickness in middle-age adults and elders. Journal of Atherosclerosis and Thrombosis 24(7): 677-686.

Yasmin, M.C.M., Wallace, S., Mackenzie, I.S., Cockcroft, J.R. \& Wilkinson, I.B. 2004. C-reactive protein is associated with arterial stiffness in apparently healthy individuals. Arteriosclerosis, Thrombosis, and Vascular Biology 24(5): 969-974.

Yousef, Q., Reaz, M.B.I. \& Ali, M.A.M. 2012. The analysis of PPG morphology: Investigating the effects of aging on arterial compliance. Measurement Science Review 12(6): 266-271.

Amilia Aminuddin*, Azizah Ugusman \& Norizam Salamt Department of Physiology

Universiti Kebangsaan Malaysia Medical Center

Jalan Yaacob Latif, Bandar Tun Razak

56000 Cheras, Kuala Lumpur, Federal Territory

Malaysia

Musilawati Muhajir

Department of Pathology

Universiti Kebangsaan Malaysia Medical Center

Jalan Yaacob Latif, Bandar Tun Razak

56000 Cheras, Kuala Lumpur, Federal Territory

Malaysia

*Corresponding author; email: amilia@ppukm.ukm.edu.my

Received: 2 April 2019

Accepted: 19 August 2019 